\title{
CONTINUITY AND DEMOGRAPHIC CYCLING IN THE ROMANIAN CARPATHIAN SPACE IN THE PERIOD 1930-2011
}

\author{
Mădălin-Sebastian LUNG * \\ Babeș-Bolyai University, Doctoral School of Geography, Cluj-Napoca, 5-7 Clinicilor Street, Romania, \\ e-mail: lungmadalin@yahoo.com
}

Citation: Lung M.-S. (2019). Continuity and Demographic Cycling in the Romanian Carpathian Space in the Period 1930-2011. Analele Universitătii din Oradea, Seria Geografie, 29(1), 79-91. https://doi.org/10.30892/auog.291109-802

\begin{abstract}
Through this article we wanted to conduct a research on the demographic component in the Romanian Carpathians by dividing the Carpathian Oicumenical into the Internal Carpathian Oicumena and External Carpathian Oicumena. We also wanted to identify cycles of demographic evolution and involutivity in the Romanian Carpathian space, and in parallel to identify several causes of different orgini that underwent the continuity and the demographic cyclical. The studied Period is 1930-2011, with statistical data taken from four censused: 1930, 1977, 1992 and 2011. Their processing was done using the Microsoft Excel 2013 program, calculating demographic increases. Then, the resulting increases served in the implementation of the database, and their processing was done through geographic information systems (ArcGis 10.3), making maps representative of the intended purpose. In 1930, the urban environment was little represented in the Romanian Carpathians, but after the establishment of socialism, the number of cities increased greatly. Instead, the rural environment began to be gradually disintegrated by the communist regime, with the population having to migrate to urban centres. On the whole, the population of the Romanian Carpathians rose from 1930 to 1977 and 1992, with the beginning of the demographic decline, with the establishment of capitalism. In the period 1977-1992, the Carpathian population increased by $5 \%$, and from 1992 to 2011 , decreased by $16 \%$.
\end{abstract}

Key words: continuity, cyclical, demography, Carpathian Space, Romania

$$
* \quad * \quad * \quad * \quad * \quad *
$$

\section{INTRODUCTION}

The diversity of geologico-geomorphological processes carried out in the Romanian Carpathians area-imposed discontinuities through the presence of depression and valley corridors. Due to the high degree of geomorphological fragmentation of the Romanian Carpathians relief, the deities and valley lanes provided favorable conditions for the placement of the settlements in the Paleolithic period. The carpathian demographic component retained its historical cycle, evolving

\footnotetext{
${ }^{*}$ Corresponding Author
} 
under the character of continuity until the contemporary period. From a structural point of view, Giurcăneanu (1988) divided the Carpathian Oicumena into: Marginal Oicumena and Internal Oicumena. I believe that these two formulations lie under the sign of ambiguity, because of the precise inaccuracy of the geographical area (Carpathian) in the composition of structures. Also, the Marginal Oicumena can lead us to something that exists outside the Carpathians, which does not belong to the Carpathian space. Thus, I propose to improve the two structures, on their merits two already mentioned, in the Internal Carpathian Oicumena and External Carpathian Oicumena. In the first structure are classified intracarpatic depression regardless of dimensions and hydrographic corridor. In the second structure, all the Carpathian space surrounding the geographical elements mentioned in the first structure, namely the high mountain areas with more or less high degree of geomorphological fragmentation (figure 1).

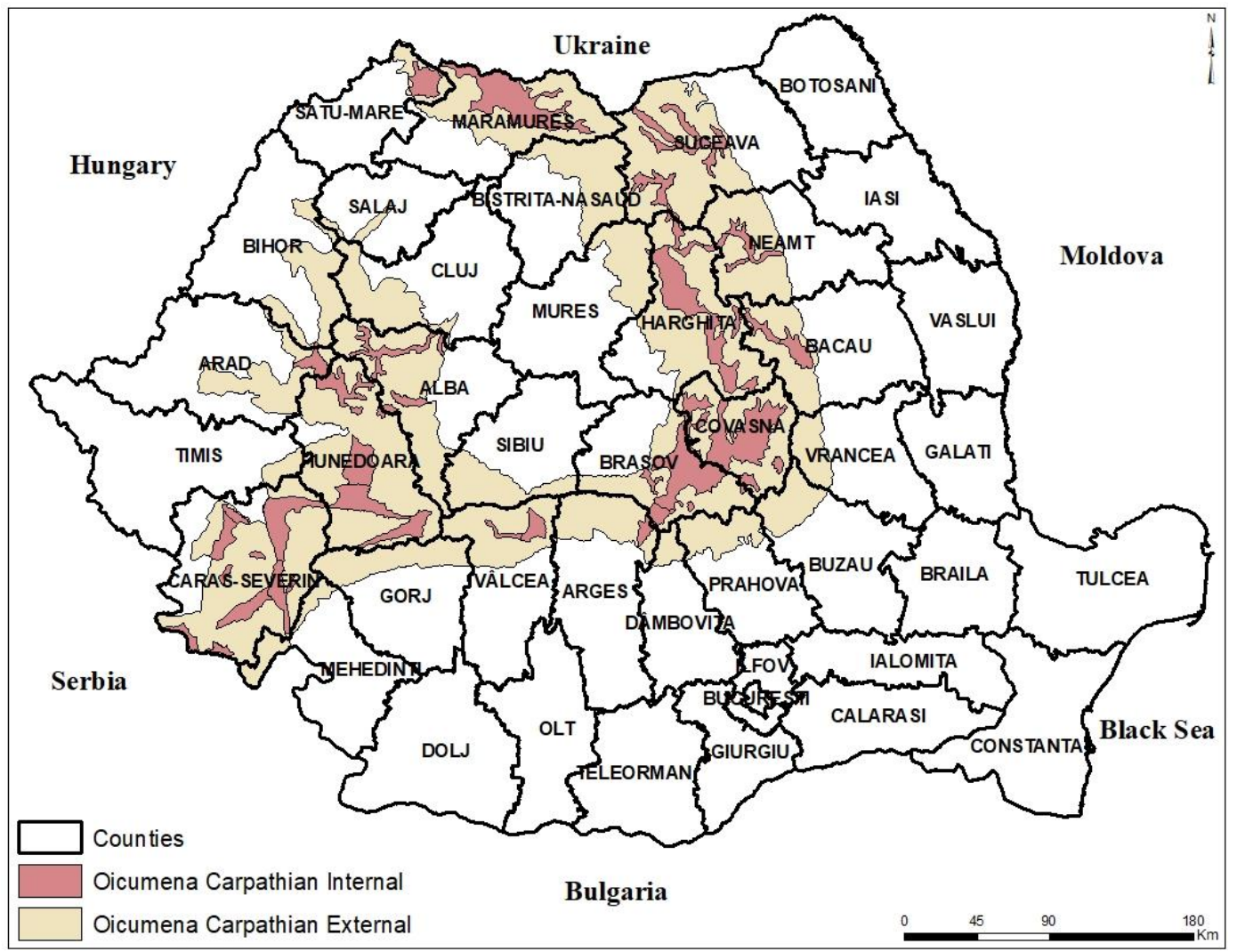

Figure 1. Oicumaines of Romanian Carpathians

(Source: own study based on Posea, Badea, 1974)

By achieving a comparative retrospective between the Romanian Carpathians and other mountainous regions, we have the opportunity to observe demographic developments and factors that have been the basis for the dynamics of the anthropogenic component. In general, mountainous regions are subject to the risk of depopulation by migrating the population from high altitudes to lower altitudes. Risk demographic phenomena have spread to many mountainous regions around the world.

Since the post-war period, the rural population of the mountains in Macedonia has fallen by $50 \%$. With the demographic decline in the rural area, dysfunctions occurred in the dimensional structure of the villages, passing from the upper class, in the lower class, due to the population 
losses (Madzevic and Toshevska, 2016). The situation of the population in the Bulgarian Mountains is similar to that of Macedonia. The depopulation of mountainous regions in Bulgaria began after the end of the last world conflagrations, preserving its continuity until 1985. After this year, it followed an intensification of the depopulation of mountainous regions, which resulted in the emergence and diversification of demographic risk phenomena (Mladenov and Ilieva, 2012). The Carpathian Mountains on the territory of Slovakia, Poland and Ukraine have depopulated especially after the disintegration of the Soviet Union. It was the starting time of a transitional period, as a result of which the mountain population abandoned land and work in the forest. The process had similar steps for the Slovak and Polish Carpathian parts (Kuemmerle et al., 2008; Angelstam et al., 2013; Warchalska-Troll and Troll, 2014; Chovankova and Mladek, 2002; Meessen et al., 2015; Solar et al., 2016; Kozak et al., 2007). The Caucasus Mountains, especially the central part, face demographic problems similar to the Romanian Carpathians. The phenomenon of depopulation, is flanked by emigration and negative natural growth, plus the continuous decline in birth rates. Following these, the phenomenon of demographic ageing occurs, $37.3 \%$ of the population having over 65 years of age. The Georgia Authorities carried out the Georgian Mountain Law, which was formulated and adopted by Parliament in 2015 and which enters into force in 2016 and 2017. The Georgian State wants to support the mountain population and again encourage the central population of the Caucasus Mountains, providing exemption for 3year taxes on investments that promote the sustainable use of local resources and employment labour force (UNDP Georgia, 2015; Kohler et al., 2017). Demographic failures, destabilise including Western Europe, specifically mountainous regions of the Iberic Peninsula. The mountainous Region of Aragon, has been heavily depopulated during the twentieth century, from 1860 to 2000, depopulating with 56\%, thus many uninhabited villages have emerged (Acin and Pinilla, 1995). The mountain economy of the Aragonzeze region is very identical to the mountain economy of the Romanian Carpathians. In comparison, both economies have two similarities: each have an autarchic model, in which the population is accustomed to obtaining all the necessary ones in their own garden, and also the population of both mountainous regions, develops economic activities traditional-rural areas such as transhumance and the realization of subsistence farming. Ayuda and Pinilla (2003), identified for the region of Aragon three decisive factors that underwent mountain depopulation (poor transport infrastructure, difficult accessibility to services and ecological restrictions). At least the first two factors identified by iberic researchers also stood to intensify the depopulation of the Romanian Carpathian space. For the revitalization of the Aragonese Mountain space, several possible avenues have been identified to halt depopulation: traditionally growing animals, woodworking activities, mining and energy production activities electric (Collantes and Pinilla, 2004).

We can say without a doubt that at least the European Mountainous regions, in the historicalgeographic period, have evolved under the scepter of continuity and demographic cycling. The risk demographic phenomena associated with the Romanian Carpathians attracted the attention of romanian researchers, who carried out a number of important studies. The most researched Carpathian Group was and is that of the Western Carpathians, especially the Apuseni Mountains. One of the most representative works, which focused on the study of the demographical risk of the Apuseni Mountains, was carried out by Surd et al., (2007). The latest book on the research of settlements in the Apuseni Mountains, deals in depth the settlements mainly in the mining areas, areas that have functioned as a demographic attraction pole (Surd et al., 2017).

\section{METHODOLOGY}

For the demographic relief of the Romanian Carpathians after the time of the Great Union of 1918, we submit to the analysis the statistical data from the census 1930 (Manuilă, 1938) 1977 (NIS), 1992 (NIS) and 2011 (NIS). The Census of 1930 gives us an insight into the carpathian demographic evolution arising from the entry of Transylvania under the subordinations of the romanian authorities. The Census of 1977, puts us in front of a positive demographical picture, 
following the anti-abortion decree promulgated a decade ago. The Last $20^{\text {th }}$-century census, made in 1992, is a statistical description of the demographic situation at the end of socialism and the beginning of capitalism. Between 1977-1992, the Carpathian demographic component was subject to large-scale population flows, predominantly in the industrial potential territories. The second census of the $21^{\text {st }}$-century, in the year 2011, cannot be omitted because of its close ties to the one in 1992. If the one in 1992 provides statistical data on the population at the beginning of the socialism-capitalism transition period, the one in 2011 provides us with statistical data on demographic evolution in the capitalist period. The statistical data was processed with the ArcGis 10.3 program, resulting in several maps from which demographic increases are apparent for each established time period. Also, several tables were generated in which there could be better emphasis on the weighting of population's demographic increases and decreases for each major group, reported in the total carpathian population and the total population of Romania.

\section{RESULTS AND DISCUSSIONS}

For the census of the year 1930, we cannot conduct a complex analysis on the two Carpathian Oicumaines or on the environments because the urban population was very low, more or less homogeneous in the Carpathian mountain space. It was only after the socialist regime was established that the network of carpathian settlements began to diversify. In the years 1954 and 1956, many cities were decreed, passing from the rank of common to the city, and during the socialist period appeared numerous new carpathian localities. The analysis desired to be carried out by us will comprise the censuses of 1977, 1992 and 2011.

In the year 1930, the Romanian Carpathians network was not very diversified, with the carpathian population of about 1,690290 inhabitants. The majority of the population was incorporated in rural areas, only about 187,095 (11\%) people living in the carpathian urban environment. At national level, the carpathian population had a weight of $9.3 \%$, and the largest share of the carpathian anthropogenic component reported in the total population of the country was $5.0 \%$. Thus, the majority of the population was widespread in the area of the Eastern Carpathians, registering 912,161 inhabitants. The Western Carpathians had a share of the national total of 2.8\%, ranking in the aftermath of the Eastern Carpathians, with the 518,340 inhabitants. The Southern Carpathians were the least populated, with 259,789 inhabitants, with a national share of only $1.4 \%$. By 1930, the Eastern Carpathians were more populated than the other carpathian groups, with a network of more branted settlements (table 1). The documentary attestations of localities provide information about the age of the habitats, and for Eastern Carpathians, two parallels could be identified. Thus, the settlements on the Transylvanian side of the Eastern Carpathians are of early attestation, and the settlements from the Moldavian side are of a younger genesis.

Table 1. Evolutions of the Romanian Carpathians population in the census of the year 1930

\begin{tabular}{|c|c|c|c|}
\hline & $\begin{array}{l}\text { Population } \\
\text { number }\end{array}$ & $\begin{array}{l}\text { Weight }(\%) \text { carpathian population } \\
\text { of total population Romania }\end{array}$ & \\
\hline Romania & 18057028 & 9.3 & \\
\hline \multirow[t]{2}{*}{$\begin{array}{l}\text { Romanian } \\
\text { Carpathians }\end{array}$} & 1690290 & & \\
\hline & & $\begin{array}{l}\text { Weight }(\%) \text { of total Romania per } \\
\text { group of Carpathians }\end{array}$ & $\begin{array}{l}\text { Weight }(\%) \text { of the } \\
\text { carpathian population on } \\
\text { each mountain group }\end{array}$ \\
\hline $\begin{array}{l}\text { Eastern } \\
\text { Carpathians }\end{array}$ & 912161 & 5.0 & 53.9 \\
\hline $\begin{array}{l}\text { Southern } \\
\text { Carpathians }\end{array}$ & 259789 & 1.4 & 15.3 \\
\hline $\begin{array}{l}\text { Western } \\
\text { Carpathians }\end{array}$ & 518340 & 2.8 & 30.6 \\
\hline
\end{tabular}


From The census of 1930 to the census of 1977, the carpathian population has risen considerably, from figure 2 to note that there have been many localities where the population has grown, more or less. Most localities had demographic increases between 0-50\%, which were distributed throughout the territory of the Romanian Carpathians.

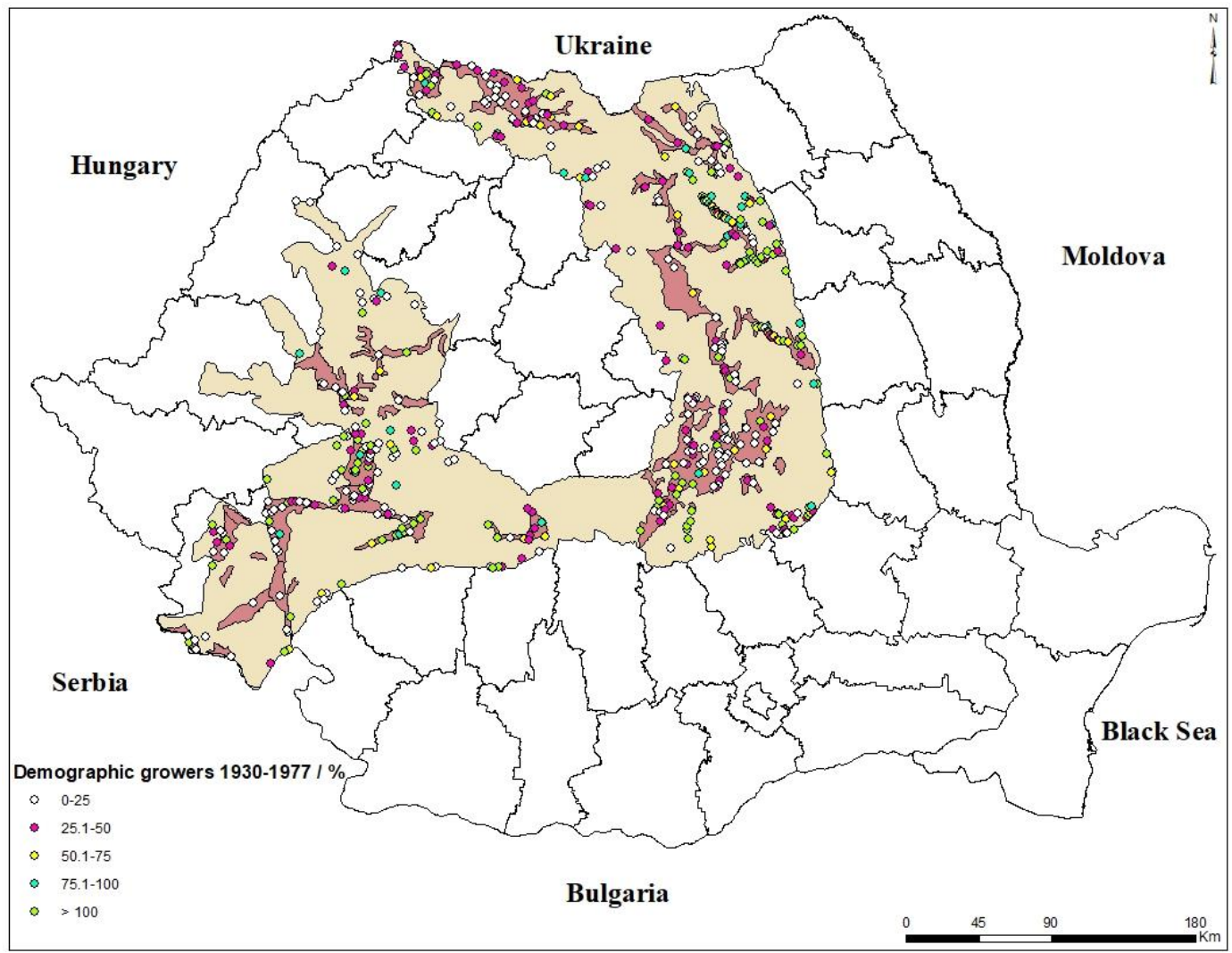

Figure 2. Demographic growth in the Romanian Carpathians in the period 1930-1977 (Source: data processed after the Manuilă, 1938; NIS)

Predominantly, the population increases occurred following the romanian leadership of the socialist regime, with the year 1948. Socialism played an important role in romania's birth, with a diverse range of solutions for demographic growth. In conjunction with the demographic solutions, a number of investments were made in the industrial sector, so that many carpathian localities, in terms of the resources they had in the administrative perimeter, were to move from the rank of common to the rank of city. Thus, the most significant demographic growth of more than $100 \%$, were mostly concentrated in new cities or in rural localities from their immediate proximity. The population increases of urban centres in the Petroșani Depression, the Prahova Valley and the Haţeg-Hunedoara Depression can be distinguished. In the eastern part of the Eastern Carpathians were formed in the period of 47 years, three nucleuses of demographic explosion. The three cores have at least one resemblance, so this is given by the linear shape of the geographic positioning, running in the longitudinal course of a hydrographic artery. The northern most nucleus was formed in the hydrographical course of Bistriţei, around the village of Broşteni. In the area of this locality, mining activities were undertaken, which boosted the workforce in neighbouring localities, to train in underground work. Mining has provided stable employment and the population has been able to evolve numerically. Along the Bicaz river is the second nucleus, constituted largely following the 
start of the construction work of the anthropic dam Izvoru Muntelui. The main settlement was the town of Bicaz, which, shortly after the completion of the works at the dam, was decreed the city. A large workforce was needed to achieve the great dam, which was brought from neighbouring localities and from other localities. In this second case, demographic prosperity was due to the hydropower industry, through the construction of the dam and the hydropower plant for electricity production. The third nucleus runs symmetrically on one side and another of the Trotuşului, respectively in the area of the Comăneşti Depression, the localities thrive due to the carbononiferous deposits. We can note that the main localities of the three cores (Broşteni, Bicaz, Comăneşti) arrived in time from the status of rural locality, to the status of urban locality. Thus, we can consider them to be local polarizing centres, with exchanges of demographic flows, information, transport with neighbouring localities.

In 1977, the Romanian Carpathian settlement network was very diversified, with a significant number of localities, compared to the census of 1930. The total carpathian po pulation was about 2,743149 inhabitants, with a share of $12.7 \%$ of Romania's total demographics. The carpathian demographic component was distributed roughly equally between the Southern Carpathians and the Western Carpathians, and more than half of the carpathian demographic was positioned in the Eastern Carpathians, relative to the total population of the Carpathians Romanian (table 2).

Table 2. Evolutions of the Romanian Carpathians population in the census of the year 1977 (Source: data processed after the NIS)

\begin{tabular}{|c|c|c|c|}
\hline & Population number & $\begin{array}{l}\text { Weight (\%) carpathian } \\
\text { population of total } \\
\text { population Romania }\end{array}$ & \\
\hline Romania & 21559910 & 12.7 & \\
\hline Romanian Carpathians & 2743149 & & \\
\hline & & $\begin{array}{l}\text { Weight (\%) of total } \\
\text { Romania per group of } \\
\text { Carpathians }\end{array}$ & $\begin{array}{l}\text { Weight }(\%) \text { of the } \\
\text { Carpathian population } \\
\text { on each mountain } \\
\text { group }\end{array}$ \\
\hline Eastern Carpathians & 1597310 & 7.4 & 58.2 \\
\hline Southern Carpathians & 540910 & 2.5 & 19.7 \\
\hline Western Carpathians & 604929 & 2.8 & 22.0 \\
\hline
\end{tabular}

Table 3. Evolutions of the Romanian Carpathians population in the census of the year 1992

\begin{tabular}{|c|c|c|c|}
\hline & Population number & $\begin{array}{c}\text { Weight }(\%) \\
\text { carpathian } \\
\text { population of total } \\
\text { population Romania }\end{array}$ & \\
\hline Romania & 22810035 & \multirow[t]{2}{*}{12.6} & \\
\hline Romanian Carpathians & 2892098 & & \\
\hline & & $\begin{array}{l}\text { Weight (\%) of total } \\
\text { Romania per group } \\
\text { of Carpathians }\end{array}$ & $\begin{array}{l}\text { Weight }(\%) \text { of the } \\
\text { carpathian population on } \\
\text { each mountain group }\end{array}$ \\
\hline Eastern Carpathians & 1753862 & 7.6 & 60.6 \\
\hline Southern Carpathians & 585411 & 2.5 & 20.2 \\
\hline Western Carpathians & 552825 & 2.4 & 19.1 \\
\hline
\end{tabular}

The Census of the year 1992 was recorded the highest effective of the carpathian population. Compared to the census of 1977, the population of the Romanian Carpathians had a demographic increase of $5 \%$. We note, the decrease in the population in Western Carpathians due 
to the beginning of the reforms to the gold mining in the Apuseni Mountains. The temporary cessation and subsequent closure of the extraction and processing activities of the auroargentiferous resources in the basement of the Apuseni led to the emergence of urban demographic failures. The urban area of Apuseni was first affected immediately after the fall of socialism, in terms of loss of jobs in the gold industry, resulting in the reorientation of the population to other cities and abroad (table 3 ).

Since the last census of the twentieth century, made in the year 1992, until the second census of the $21^{\text {st }}$-century, carried out in the year 2011 , the carpathian population decreased, being recorded the demographic minimum of the period 1977-2011 (table 4). The Carpathian Space depopulated from 1992 to 2011 by $16 \%$, while registering the lowest share of the total population of Romania. The carpathian demographic component had 2011, 11.9\% of the total population of Romania. One of the causes that led to a decrease in the population was the repeal of Decree 770 of 1966 on anti-abortion, which was in conjunction with the loss of the basic economic functions of localities, in the immediate beginning of capitalism.

Table 4. Evolutions of the Romanian Carpathians population in the census of the year 2011

\begin{tabular}{|c|c|c|c|}
\hline & $\begin{array}{c}\text { Population } \\
\text { number }\end{array}$ & $\begin{array}{l}\text { Weight (\%) carpathian population } \\
\text { of total population Romania }\end{array}$ & \\
\hline Romania & 20121641 & 11.9 & \\
\hline Romanian Carpathians & 2401906 & & \\
\hline & & $\begin{array}{l}\text { Weight }(\%) \text { of total Romania per } \\
\text { group of Carpathians }\end{array}$ & $\begin{array}{l}\text { Weight }(\%) \text { of the } \\
\text { carpathian population on } \\
\text { each mountain group }\end{array}$ \\
\hline Eastern Carpathians & 1525940 & 7.5 & 63.5 \\
\hline Southern Carpathians & 452553 & 2.2 & 18.8 \\
\hline Western Carpathians & 423413 & 2.1 & 17.6 \\
\hline
\end{tabular}

The 1977-1992 period was marked by demographic increases among the urban population both in urban localities in the Internal Carpathian Oicumena and in the localities of the External Carpathian Oicumena. The increases were especially noted in the urban carpathians in the Internal Carpathian Oicumena, where the geographical position was net influenced by the presence of subsolic resources, which socialism exploited intensively (table 5 ). The urban carpathian population prospered during the 15 years with $20.4 \%$, resulting in intensification of the carpathian urbanization process.

Table 5. Evolution of the carpathian urban population in the period 1977-1992

(Source: data processed after the NIS)

\begin{tabular}{|c|c|c|c|c|c|}
\hline & $\begin{array}{c}\text { Internal Carpathian } \\
\text { Urban Population } 1977\end{array}$ & $\begin{array}{c}\text { Internal Carpathian } \\
\text { Urban Population } \\
1992\end{array}$ & $\begin{array}{c}\text { Increases/decreases } \\
1977-1992 \\
\%\end{array}$ & $\begin{array}{c}\% \text { of total } \\
1977\end{array}$ & $\begin{array}{c}\% \text { of total } \\
1992\end{array}$ \\
\hline $\begin{array}{l}\text { Eastern } \\
\text { Carpathians }\end{array}$ & 673585 & 854687 & 26.8 & 48.4 & 51.0 \\
\hline $\begin{array}{l}\text { Southern } \\
\text { Carpathians }\end{array}$ & 313351 & 372299 & 18.8 & 22.5 & 22.2 \\
\hline \multirow[t]{2}{*}{$\begin{array}{l}\text { Western } \\
\text { Carpathians }\end{array}$} & 181761 & 206787 & 13.7 & 13.0 & 12.3 \\
\hline & $\begin{array}{l}\text { External Carpathian } \\
\text { Urban Population } 1977\end{array}$ & $\begin{array}{c}\text { External Carpathian } \\
\text { Urban Population } \\
1992\end{array}$ & & & \\
\hline $\begin{array}{l}\text { Eastern } \\
\text { Carpathians }\end{array}$ & 118897 & 128247 & 7.8 & 8.5 & 7.6 \\
\hline $\begin{array}{l}\text { Southern } \\
\text { Carpathians }\end{array}$ & 54116 & 67432 & 24.6 & 3.8 & 4.0 \\
\hline $\begin{array}{l}\text { Western } \\
\text { Carpathians }\end{array}$ & 48043 & 44855 & -6.6 & 3.4 & 2.6 \\
\hline Total & 1389753 & 1674307 & 20.4 & & \\
\hline
\end{tabular}


The Communist Era was a thriving period for Romania, with socialism putting great emphasis on urbanization. The Romanian Carpathians were more urbanised, and new cities were decreed, based on economic policies. Several urban centres were passed to the rank of the city due to the existence in the administrative territory of subsolic resources. In the Apuseni Mountains, there is probably the most eloquent example of the carpathian city formed due to the golden Subsolic resources, whose extraction, processing and marketing has begun since the Dacian period. In the course of time, Zlatna had different economic roles, which in the period of socialism brought him the title of city, considered to be a real center for exploitation, administration, processing of the auro-argentiferous resources. The genesis of other cities was the coal resources, which by the scale of the holdings were the population of demographic attraction. This is the case, the urban carboniferous centres of Petroșani Depression: Uricani, Lupeni, Petrila, Vulcan, but also of the cities of the Apusenii Bihorului: Nucet, Ştei, Vaşcău.

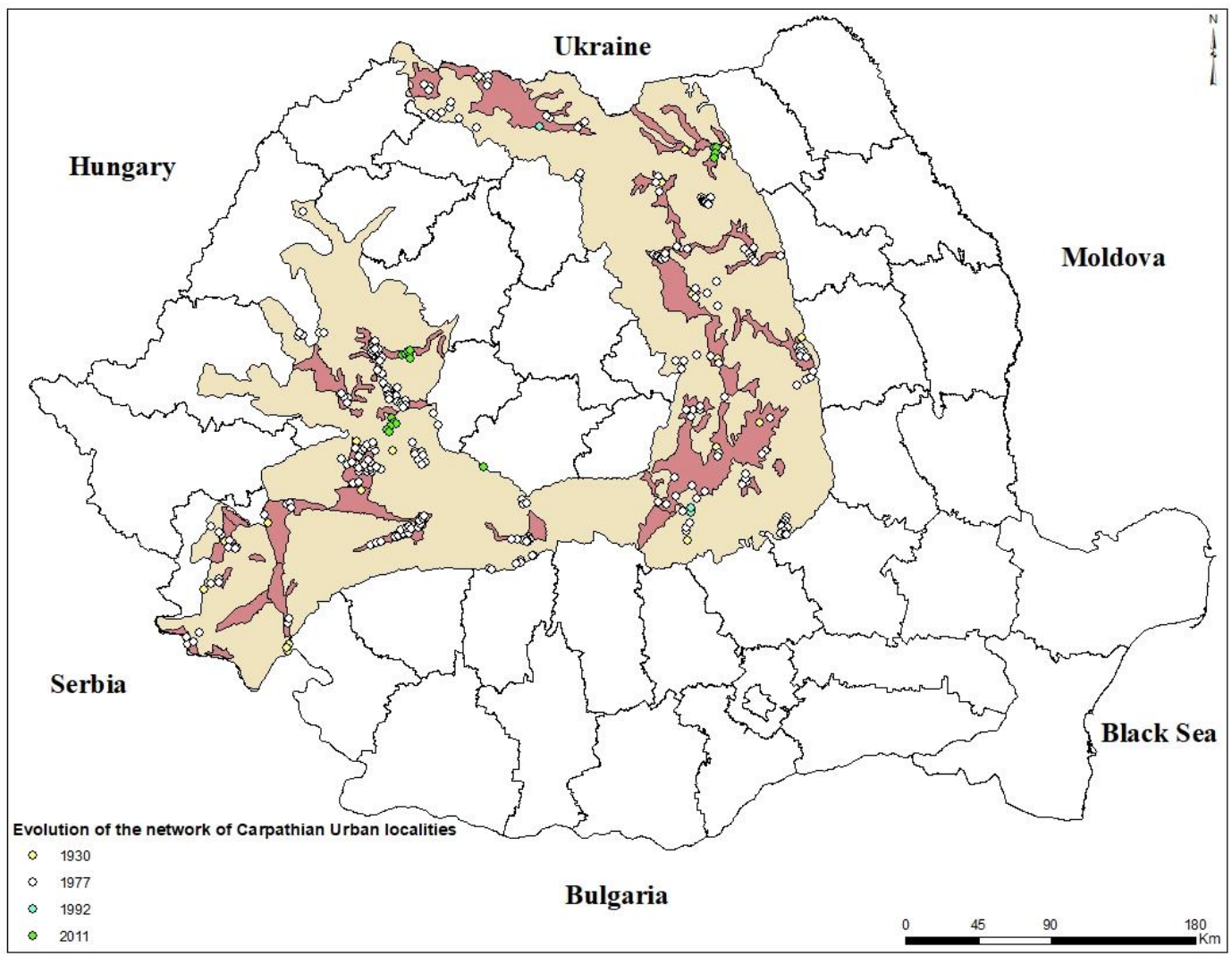

Figure 3. Evolution of the urban localities network in the Romanian Carpathians in the period 1930-2011 (Source: data processed after the Suciu, 1967-1968; Manuilă, 1938)

An important evidence of the urbanization of the Romanian Carpathians, is the documentary attestations of urban localities, from which we can see the evolution of the network of urban carpathian localities. At the census in the year 1930, the first, carried out after the Great Union of the year 1918, the carpathian urban environment consisted only of several localities, distributed unhomogenous in the territory. The numerical climax of urban localities in the Romanian Carpathians was recorded in the Census of the year 1977. Most of the urban explosion took place amid the subsolic resources found in the vicinity of localities, in which the authorities passed from the rank of rural village to the rank of urban locality. By this way, the Romanian 
Carpathian Space has been in a period of only a few years, scraped by urban localities, expanded throughout the territory. However, urbanisation has produced something more pronounced in the ways where there have been natural resources of great importance for the good economic functioning of the country. Thus, we can see, the urban carboniferous groups of the Petroşani Depression (Jiului Valley), the Haţeg-Hunedoara Depression and the urban auriferous groups in the heart of the Apuseni Mountains, developed around the tradition centers on the exploitation and processing the gold, Zlatna, Abrud and Câmpeni. The Census of the year 1992, brings few new urban (Predeal, Timiş de Sus, Săliştea de Sus) but something more than 1992, are contained in the census of 2011 (Frasin, Geoagiu-Băi, Baia de Arieş), each with their constituent localities (figure 3).

If urban space prospered from 1977-1992, the rural area began to disintegrate gradually following the reforms of communism on the systematization of rural and urban localities (table 6). The new territorial organisation, whereby the authorities wished to increase the well-being of the anthropic component and the harmonious development of the habitat, was based on Law 58 of the year 1974. To a large extent systematization was a socialist process that wanted the relocation of the rural population to cities. On the tables of evolution of the urban and rural population of the 1977-1992 gauge, we can say that the process has succeeded to some extent, since the rural population has been displaced or forced to migrate to the urban environment. As evidence, there are impressive percentage rural demographic decreases in table 6 , which highlight the desired success of the socialists.

Table 6. Evolution of the carpathian rural population in the period 1977-1992

(Source: data processed after the NIS)

\begin{tabular}{|c|c|c|c|c|c|}
\hline & $\begin{array}{c}\text { Internal Carpathian } \\
\text { Rural Population } \\
1977 \\
\end{array}$ & $\begin{array}{c}\text { Internal } \\
\text { Carpathian Rural } \\
\text { Population } 1992 \\
\end{array}$ & $\begin{array}{c}\text { Increases/decreases } \\
1977-1992 \\
\% \\
\end{array}$ & $\begin{array}{l}\% \text { of } \\
\text { total } \\
1977 \\
\end{array}$ & $\begin{array}{l}\% \text { of } \\
\text { total } \\
1992 \\
\end{array}$ \\
\hline $\begin{array}{l}\text { Eastern } \\
\text { Carpathians }\end{array}$ & 599446 & 566161 & -5.5 & 44.2 & 46.4 \\
\hline $\begin{array}{l}\text { Southern } \\
\text { Carpathians }\end{array}$ & 82439 & 69269 & -15.9 & 6.0 & 5.6 \\
\hline \multirow[t]{2}{*}{$\begin{array}{l}\text { Western } \\
\text { Carpathians }\end{array}$} & 176105 & 150975 & -14.2 & 13.0 & 12.4 \\
\hline & $\begin{array}{c}\text { External Carpathian } \\
\text { Rural Population } \\
1977\end{array}$ & $\begin{array}{c}\text { External } \\
\text { Carpathian Rural } \\
\text { Population } 1992\end{array}$ & & & \\
\hline $\begin{array}{l}\text { Eastern } \\
\text { Carpathians }\end{array}$ & 205382 & 204767 & -0.2 & 15.1 & 16.8 \\
\hline $\begin{array}{l}\text { Southern } \\
\text { Carpathians }\end{array}$ & 91004 & 76411 & -16 & 6.7 & 6.2 \\
\hline $\begin{array}{l}\text { Western } \\
\text { Carpathians }\end{array}$ & 199020 & 150208 & -24.5 & 14.7 & 12.3 \\
\hline Total & 1353396 & 1217791 & -10 & & \\
\hline
\end{tabular}

At the local level, the demographic increases in the period 1977-1992 are shown in figure 4. Compared to the previous period, we note the increased density of localities that have seen demographic growth. Most of the increases were between 0-25\%, comprising almost entirely the carpathian space. In the Apuseni Mountains, there were demographic elevations in localities near the mining-argentiferous mines. Unfortunately, the desire to exploit the Western gold intensively led to the incise of the rural exodus. Villages of the type specific to these mountains, gradually depopulated, the population being constrained by the authorities to descend towards the mining tunnels. 


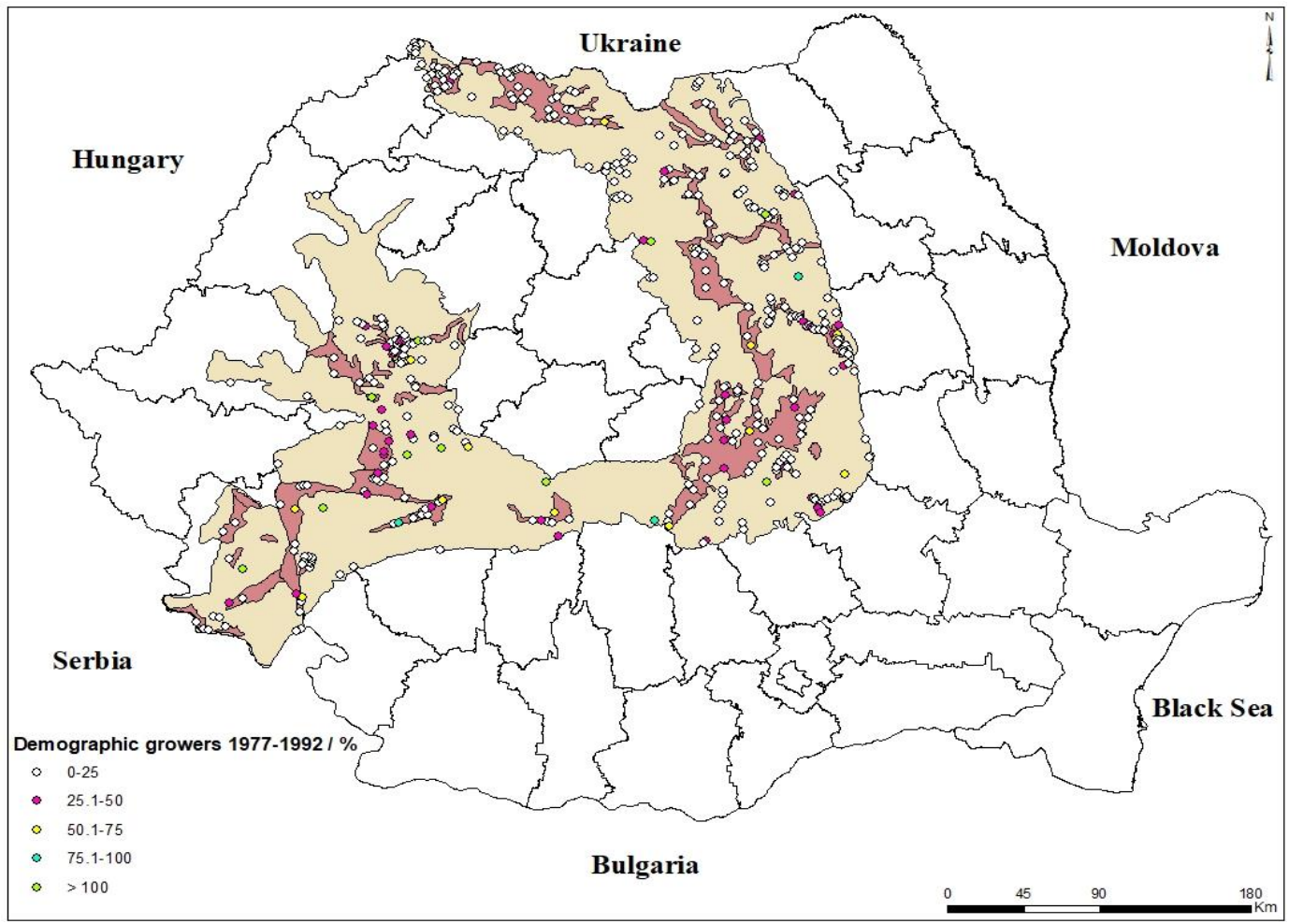

Figure 4. Demographic growth in the Romanian Carpathians in the period 1977-1992

(Source: data processed after the NIS)

From 1992 to 2011, the Romanian Carpathians began to lose significant demographic growth, both in urban and rural areas, the latter preserving the continuity of the decline begun during the Communist Era. On the weights of the decreases, the urban population of the Internal Carpathian Oicumena had slightly lower values than the urban weights of the External Carpathian Oicumena. However, the decreases are high given the short period of time. Basically, the massive urbanization of the Golden Age period began in the last decade of the twentieth century, a visible demographic decline. Each mountain group began to lose urban populations because of industrial restructuring, which had been in the past at the base of urbanisation. The urban environment of the External Carpathian Oicumena was faster and more aggressively subjected to depopulation, in the light of the fact that the geographical position did not provide them with natural resources of importance by which it could thrive (table 7).

The rural population of the Romanian Carpathians retained its downward trend throughout the 34 years, from 1977 to 2011. The Period of domination of the rural population in the carpathians ended with the abdication of King Mihai I, the moment represented by the change in the form of government in the monarchy in the republic. Also, the change in the form of government coincided with the country's leadership, the socialist regimes taking place a succession of them until 1989. From that moment on, the carpathian countryside was to enter decisively under the wand of major economic-political-social mutations, leading shortly to the beginning of the process of habitat and demographic involution. After nearly half a century of carpathian rural destructuring, neither the new world of capitalism has yet found the necessary methods of revitalizing the rural area. After 1989, the Westerners ' rural environment had the biggest dysfunctions, losing more and more young people from year to year, which migrated to urban centres where access to education, health and other services is much easier (table 8). 
Table 7. Evolution of the carpathian urban population in the period 1992-2011 (Source: data processed after the NIS)

\begin{tabular}{|c|c|c|c|c|}
\hline & $\begin{array}{c}\text { Internal Carpathian } \\
\text { Urban Population 1992 }\end{array}$ & $\begin{array}{c}\text { Internal Carpathian } \\
\text { Urban Population 2011 }\end{array}$ & $\begin{array}{c}\text { Increases/decreases } \\
1992-2011 \\
\%\end{array}$ & $\begin{array}{c}\% \text { of total } \\
2011\end{array}$ \\
\hline $\begin{array}{c}\text { Eastern } \\
\text { Carpathians }\end{array}$ & 854687 & 711025 & -16.8 & 53.3 \\
\hline $\begin{array}{c}\text { Southern } \\
\text { Carpathians }\end{array}$ & 372299 & 278783 & -25.1 & 20.9 \\
\hline $\begin{array}{c}\text { Western } \\
\text { Carpathians }\end{array}$ & 206787 & 161001 & -22.1 & 12 \\
\hline $\begin{array}{c}\text { External Carpathian } \\
\text { Eartern }\end{array}$ & $\begin{array}{c}\text { External Carpathian } \\
\text { Urban Population 2011 }\end{array}$ & -22.9 & 7.4 \\
\hline $\begin{array}{c}\text { Southern } \\
\text { Carpathians }\end{array}$ & 128247 & 98865 & -26.6 & 3.7 \\
\hline $\begin{array}{c}\text { Western } \\
\text { Carpathians }\end{array}$ & 44852 & 49446 & -23.6 & 2.5 \\
\hline Total & 1674307 & 34237 & & \\
\hline
\end{tabular}

Table 8. Evolution of the carpathian rural population in the period 1992-2011 (Source: data processed after the NIS)

\begin{tabular}{|l|c|c|c|c|}
\hline & $\begin{array}{l}\text { Internal Carpathian } \\
\text { Rural Population 1992 }\end{array}$ & $\begin{array}{l}\text { Internal Carpathian } \\
\text { Rural Population 2011 }\end{array}$ & $\begin{array}{l}\text { Increases/decreases } \\
\text { 1992-2011 } \\
\%\end{array}$ & $\begin{array}{c}\% \text { of } \\
\text { total } \\
2011\end{array}$ \\
\hline $\begin{array}{l}\text { Eastern } \\
\text { Carpathians }\end{array}$ & 566161 & 530386 & -6.3 & 49.6 \\
\hline $\begin{array}{l}\text { Southern } \\
\text { Carpathians }\end{array}$ & 69269 & 58312 & -15.8 & 5.4 \\
\hline $\begin{array}{l}\text { Western } \\
\text { Carpathians }\end{array}$ & 150975 & 119855 & -20.6 & 11.2 \\
\hline $\begin{array}{l}\text { External Carpathian } \\
\text { Rural Population 1992 }\end{array}$ & $\begin{array}{l}\text { External Carpathian } \\
\text { Rural Population 2011 }\end{array}$ & & \\
\hline $\begin{array}{l}\text { Southern } \\
\text { Carpathians }\end{array}$ & 204767 & 185664 & -9.3 & 17.3 \\
\hline $\begin{array}{l}\text { Western } \\
\text { Carpathians }\end{array}$ & 76411 & 66012 & -27.8 & 10.1 \\
\hline Total & 150208 & 108320 & -12.2 & \\
\hline
\end{tabular}

The number of localities that have increased demographical, decreased in the post-socialist period, and increases in the period 1992-2011 are predominantly dominated by values between 0$25 \%$. The abundance of increases concentrated in the southern parts of the Eastern Carpathians, in the central part and at the southern tip of the Apuseni Mountains. Unfortunately, the number of localities that have grown from a demographic point of view has declined from one census to another. The dominant Increases were between the values of 0-25\%, and from 1992 onwards, many carpathian localities had a demographic deficit, losing the constant and continuous population (figure 5). 


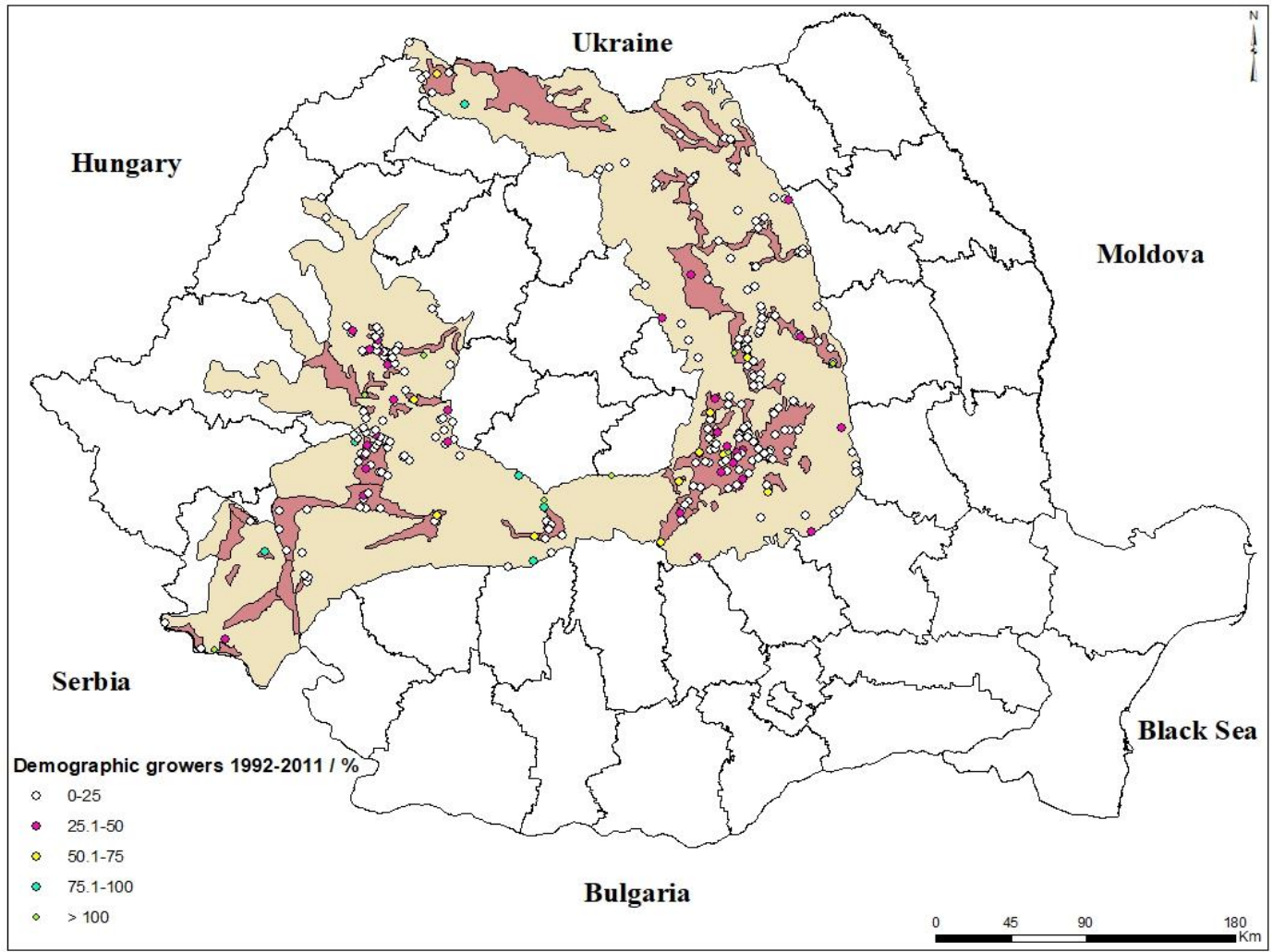

Figure 5. Demographic growth in the Romanian Carpathians in the period 1992-2011 (Source: data processed after the NIS)

\section{CONCLUSIONS}

The population of the Romanian Carpathians was continuously dynamic in the period 19302011, with periods of growth and decreasing periods. By dividing the period mentioned on several other sub-periods, we can identify upward and descending demographic cycles. From 1930 to 1977, the Romanian Carpathian Space, recorded a first positive demographic cycle, continued with the period 1977-1992, when the second positive demographic cycle was recorded. The 1977-1992 demographic cycle was the most prolific, with impressive demographic growth, started especially after Decree 770, on the prohibition of aborts. Also, the urban network of localities, was much diversified, amid natural resources being decreed new and new cities, taking place a broad process of carpathian urbanization. Unfortunately, in the period 1992-2011, the negative demographic cycle was identified, in which the population of the Romanian Carpathians decreased considerably. Thus, during the second decade of the interwar period, containing with the periods of socialist regimes, the carpathian population prospered continuously. The demographical impasse began with the establishment of capitalism, which came with new changes in most of the plans, adversely affecting the demographic component.

\section{REFERENCES}

Acin, J.L., Pinilla, V. (1995). Pueblos abandonados: un mundo perdido, Zaragoza.

Angelstam, P., Elbakidze, M., Axelsson, R., Cupa, P., Halada, L., Molnar, Z., Patru Stupariu, I., Perzanowski, K., Rozulowicz, L., Standovar, T., Svoboda, M., Tornblom, J. (2013). Maintaining cultural and natural biodiversity in the Carpathian mountain ecoregion: Need for an integrated landscape approach. In: Kozak J, Ostapowicz K, Bytnerowicz A, Wyzga 
B, editors. The Carpathians: Integrating Nature and Society Towards Sustainability, Environmental Science and Engineering. Berlin and Heidelberg, Germany: Springer, pp. 393-424.

Ayuda, M.I., Pinilla, V. (2003). El proceso de desertizacion demografica de la montana pirenaica en el largo plazo: Aragon, Ager. Journal of Depopulation and Rural Development Studies, 2, 101-138.

Chovankova, J., Mladek, J. (2002). Population. In: Landscape Atlas of the Slovak Republic. Bratislava, Ministry of Environment, and Slovak Environmental Agency. pp. 150-170.

Collantes, F., Pinilla, V. (2004). Extreme Depopulation in the Spanish Rural Mountain Areas: A Case Study of Aragon in the Nineteenth and Twentieth Centuries. Rural History, 15(2): 149-166.

Giurcăneanu, C. (1988). Populaţia şi așezările din Carpaţii Româneşti [Population and settlements in the Romanian Carpathians], Editura Ştiinţifică şi Enciclopedică, București.

Kohler, T., Elizbarashvili, N., Meladze, G., Svanadze, D., Meessen, H. (2017). The Demogeographic Crisis in Racha, Georgia: Depopulation in the Central Caucasus Mountains. Mountain Research and Development, 37(4): 415-424.

Kozak, J., Estrequil, C., Troll, M. (2007). Forest cover change in the Northern Carpathians in the 20th Century: A slow transition. Journal of Land Use Science, 2(2):127-146.

Kuemmerle, T., Hostert, P., Radeloff, V., van der Linden, S., Perzanowski, K., Kruhlov, I. (2008). Cross-border comparison of post-socialist farmland abandonment in the Carpathians. Ecosystems, 11, 614-628.

Madzevic, M., Toshevska, B. (2016). Usage of the mountain areas in the Republic of Macedonia. In: Zhelezov G, editor. Sustainable Development in Mountain Regions of South Eastern Europe, $2^{\text {nd }}$ edition. Cham, Switzerland: Springer, pp. 79-91.

Manuilă, S. (1938). Recensământul general al populaţiei României: din decemvrie 1930. Vol. 1: Sex, stare civilă, grupe de vârstă, gospodării, infirmităţi, populaţia flotantă [General Census of Romanian population: from the December 1930. Vol 1: Sex, marital status, age groups, households, infirmities, floating population], Editura Institutului Central de Statistică, București.

Meessen, H., Svajda, J., Kohler, T., Fabriciusova, V., Galvanek, D., Bural, M., Kacerova, M., Kadlecik, J. (2015). Protected areas in the Slovak Carpathians as a contested resource between metropolisation and mountain stakeholders. Journal of Alpine Research, 103(3), 1-19.

Mladenov, C., Ilieva, M. (2012). The depopulation of the Bulgarian villages. In: Szymanska D, Bieganska J, editors. Bulletin of Geography. Socio-economic Series, 17, 99-107.

Posea, G., Badea, L. (1984). România. Unitățile de relief (Regionarea geomorfologică) [Romania. Relief Units (geomorphological Regionation)], Editura Științifică și Enciclopedică, București.

Solar, J., Janiga, M., Markuljakova, K. (2016). The socioeconomic and environmental effects of sustainable development in the Eastern Carpathians, and protecting its environment. Polish Journal of Environmental Studies, 25(1): 291-300.

Suciu, C. (1967-1968). Dicţionar istoric al localităţilor din Transilvania [Historical Dictionary of localities in Transylvania], Editura Academiei Republicii Socialiste România, Iași.

Surd, V., Zotic, V., Puiu, V., Moldovan, C. (2007). Riscul demografic în Munţii Apuseni [Demographical Risk in the Apuseni Mountains], Editura Presa Universitară Clujeană, Cluj-Napoca.

Surd, V., Constantin, V., Nicula, A-S. (2017). Aşezările din Munţii Apuseni [Settlements in the Apuseni Mountains], Editura Presa Universitară Clujeană, Cluj-Napoca.

UNDP [United Nations Development Programme] Georgia. 2015. Georgia adopts a law on the development of mountainous regions. http://www.ge.undp.org/content/georgia/en/home/presscenter/pressreleases/2015/07/31/georgia-adopts-alaw-on-the-development-ofmountainous-regions-.html; accessed on 19 March 2019.

Warchalska-Troll, A., Troll, M. (2014). Summer livestock farming at the crossroads in the Ukrainian Carpathians. Mountain Research and Development, 34(4): 344-355.

***Institutul Național de Statistică, National Institute of Statistics, http://statistici.insse.ro/shop/index.jsp?page=tempo2\&lang=ro\&context=45 accessed 10 January 2019.

***Decret $n r .770$ din 1 octombrie 1966 pentru reglementarea întreruperii cursului sarcinii. Act emis de: Consiliul de Stat al Republicii Socialiste România. Act publicat în: Buletinul Oficial nr. 60 din 1 octombrie 1966 [Decree nr. 770 of 1 October 1966 for regulating the interruption of the course of pregnancy. Act issued by: State Council of the Socialist Republic of Romania. Act published in: Official Bulletin nr. 60 of 1 October 1966]; http://www.legex.ro/Decretul770-1966-363.aspx accessed 20 March 2019.

***Legea $\mathrm{nr} .58$ din 29 octombrie 1974 privind sistematizarea teritoriului și localităților urbane și rurale, Act emis de: Marea Adunare Națională, Act publicat în: Buletinul Oficial nr. 135 din 1 noiembrie 1974 [Law No. 58 of 29 October 1974 on the systematization of urban and rural territory and localities. Act issued by: Grand National Assembly. Act published in: Official Bulletin $n r .135$ of 1 November 1974]; http://www.legex.ro/Legea-58-1974-565.aspx accessed 20 March 2019.

Submitted:

January 22, 2019
Revised:

March 13, 2019
Accepted and published online

May 14, 2019 